\title{
Persiapan Persalinan dan Kelahiran Di Masa Pandemi COVID-19
}

\author{
Mardiana Ahmad*1, Andi Nilawati Usman'2, Sharvianty Arifuddin ${ }^{3}$, Patmahwati ${ }^{4}$ \\ 1,2,3Prodi S2 Ilmu Kebidanan,Program Pascasarjana Universitas Hasanuddin \\ ${ }^{4}$ Prodi Kebidanan,Universitas Muhammadiyah Palopo \\ *e-mail: mardianaahmad@pasca.unhas.ac.id ${ }^{1}$, \\ andinilawati@pasca.unhas.ac.id²,sharviantyspog@gmail.com³,patmapadri85@gmail.com4
}

\begin{abstract}
Abstrak
Pandemi COVID-19 berdampak di segala aspek, salah satunya adalah aspek Kesehatan yang megakibatkan kegiatan langsung tatap muka dengan tenaga kesehatan dalam pelayanan Antenatal Care (ANC) di batasi. Hal tersebut menimbulkan kecemasan bagi ibu hamil dalam menghadapi persalinan dan kelahiran mereka. Berdasarkan kondisi tersebut, maka pengabdian masyarakat dilaksanakan dengan cara sosialisasi peningkatan dan pengetahuan ibu hamil tentang persiapan persalinan dan kelahiran di masa pandemi COVID-19. Pelaksanaan sosialisasi dilaksanakan dengan 2 pendekatan yaitu survei daring dengan eform melalui media whatsapp dan menemui secara lagsung ibu-ibu yang sedang hamil dari rumah ke rumah yang tentu saja dilaksanakan sesuai protokol Kesehatan COVID-19. Hasil survey didapatkan pada kelompok yang memakai google form pengetahuan pretest didapatkan nilai rata-rata $49 \%$ meningkat setelah posttest menjadi $89 \%$. Sedangkan pada kelompok yang kunjungan rumah pengetahuan pretest didapatkan hasil $47 \%$ meningkat setelah posttest menjadi 87\%. Pelaksanaan pengabdian ini berjalan lancar karena didukung oleh pemerintah dan masyarakat sekitar. Kedepannya diharapkan sosialisasi seperti ini dapat diterapkan oleh stakeholder dalam menangani dan mengambil kebijakan kesehatan terkait dengan pelayanan Kesehatan kepada ibu hamil di masa pandemi saat ini.
\end{abstract}

Kata Kunci : Antenatal Care, Ibu hamil, Persiapan Persalinan, COVID-19

\begin{abstract}
The COVID-19 pandemic has an impact in all aspects, one of which is the health aspect which results in limited face-to-face activities with health workers in Antenatal Care (ANC) services. This raises anxiety for pregnant women in dealing with their labor and birth. Based on these conditions, community service is carried out by socializing the increase and knowledge of pregnant women about preparation for labor and birth during the COVID-19 pandemic. The implementation of socialization was carried out with 2 approaches, namely online surveys with e-form through WhatsApp media and directly meeting pregnant women from house to house which of course was carried out according to the COVID-19 Health protocol. The survey results obtained in the group that used the google form pretest knowledge obtained an average value of $49 \%$ increased after posttest to $89 \%$. Whereas in the group who visited the pretest knowledge home, the results were $47 \%$ increased after posttest to $87 \%$. The implementation of this service runs smoothly because it is supported by the government and the surrounding community. In the future, it is hoped that this kind of socialization can be applied by stakeholders in handling and making health policies related to health services for pregnant women during the current pandemic.
\end{abstract}

Keywords: Antenatal Care, Pregnant Women, Preparation for Childbirth, COVID-19

\section{PENDAHULUAN}

Severe Acute Respiratory Syndrome Coronavirus-2 (SARS-CoV-2)awalnya ditemukan pada desember akhir 2019 diTiongkok. WHO telah mengumumkan COVID-19 sebagai pandemic 12 Maret 2020. Infeksi COVID-19 dapat menimbulkan gejala berupademam (suhu >380C), batuk, dan kesulitanbernafas selain itu dapat juga disertai sesakmemberat, fatique, myalgia, gejalagastrointestinal seperti diare dan gejala salurannafas. Dalam kasus yang sangat berat dapatmengalami perburukan yang cepat dan progresif.Selain itu, penyakit komorbid dan bawaan dapatmenjadi perburukan gejala seperti diabetesmelitus, hipertensi, penyakit jantung, dan lainlain. Cara penularan virus ini adalah melaluikontak langsung dengan percikan dari salurannapas orang yang terinfeksi (melalui batuk danbersin) dan juga jika menyentuh permukaan yangterkontaminasi virus ini lalu menyentuhwajahnya (mata, hidung, mulut) [1][2].

Komponen yang sangat penting dalam penatalaksanaan penyakit menular adalah populasi yang rentan seperti ibu hamil. Wanita hamil dan janinnya merupakan populasi berisiko 
tinggi selama penularan wabah penyakit. Hingga saat ini, hasil dari 55 ibu hamil yang terinfeksi COVID-19 dan 46 neonatus telah dilaporkan dalam literatur, tanpa bukti pasti vertical penularan. Perubahan fisiologis dan mekanis dalam kehamilan meningkatkan kerentanan terhadap infeksi secara umum, terutama bila sistem kardiorespirasi terpengaruh, dan mendorong perkembangan cepat ke gagal napas pada ibu hamil [3].

Pencegahan penyebaran virus perlu penerapan perilaku hidup bersih dan sehat, seperti mencuci tangan 6 langkah dengan sabun dan air mengalir, menerapkan physical distancing, menggunakan masker saat beraktivitas, menutupi mulut hidung ketika bersin dan batuk, membersihkan permukaan benda yang sering disentuh dan lain-lain. Namun, masyarakat masih ada yang tidak peduli atau belum sadar, bahkan belum tahu pentingnya penerapan hidup bersih dan sehat ini [4].

Pada situasi pandemi COVID-19 ini, pemerintah membuat kebijakan adanya pembatasan hampir pada semua layanan rutin salah satu contohnya adalah pelayanan kesehatan maternal dan neonatal dan fasilitas pelayanan kesehatan lainnya. Hal ini menyebabkan timbulnya kecemasan dari ibu hamil sehingga menunda melaksanakan pemeriksaan kehamilan [5].

Untuk mengatasi kecemasan ibu hamil dalam menghadapi persalinan di masa pandemi saat ini maka penyuluhan ini di laksanakan, harapannya untuk meningkatkan pengetahuan ibu hamil dalam menghadapi persalinan di masa pandemi COVID-19. Upaya tersebut merupakan salah satu strategi penyuluhan di masa pandemic dengan tetap melakukan protokol Kesehatan yang sesuai.

\section{METODE}

Pelaksanaan penyuluhan ini berupa penyuluhan tentang persiapan persalinan di masa pandemi covid-19. Dilaksanakan dengan dua pendekatan yaitu survei daring dengan menggunakan google form (pretest dan posttest) dan mengunjungi ibu hamil dari rumah ke rumah (pretest dan posttest) dengan tetap menerapkan protokol COVID-19 serta melibatkan 50 peserta penyuluhan Berikut flow chart pelaksaanaan program. 


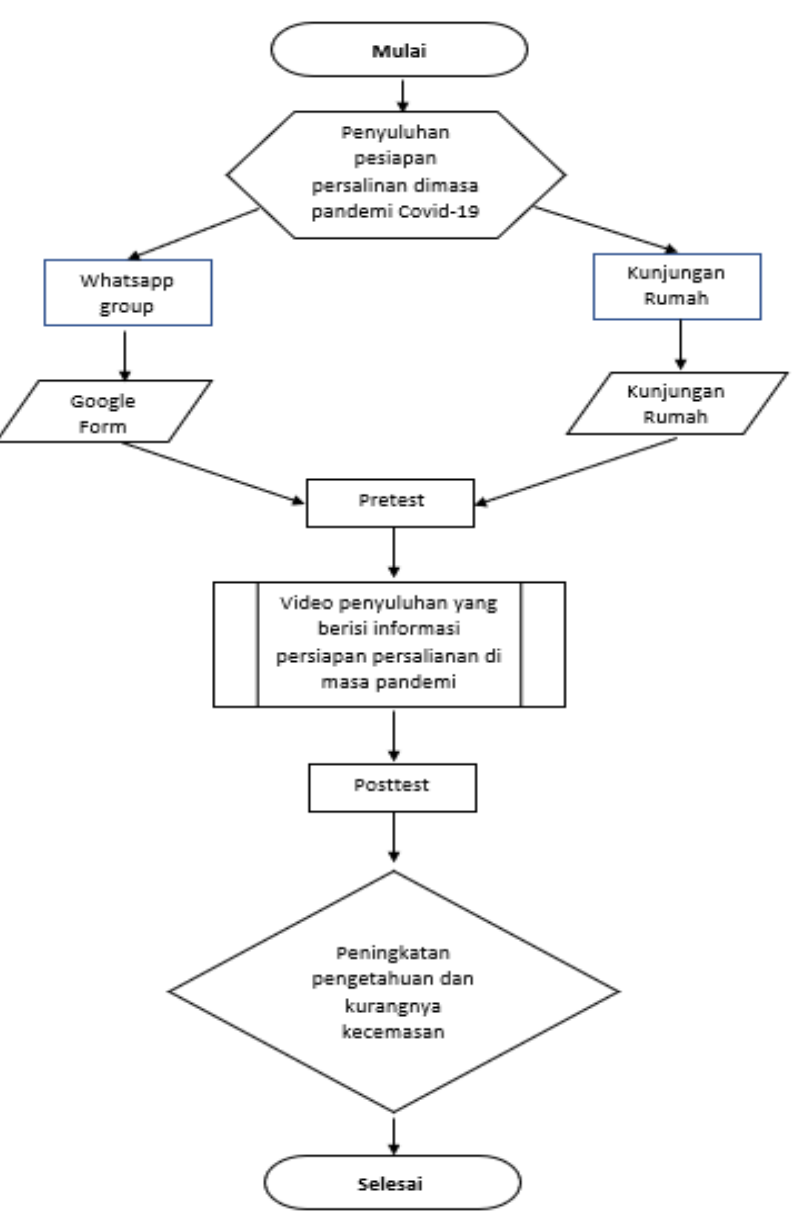

Gambar 1. Flow Chart Pelaksanaan Kegiatan

\section{Survei dan Analisis}

Survei yang didapatkan bahwa ibu hamil merasa cemas dan takut ke tempat pelayanan Kesehatan untuk memeriksakan kehamilannya serta kurangnya informasi yang didapatkan tentang persiapan persalinan dan kelahiran dimasa pandemi.

\section{Perumusan Masalah dan Pengembangan Solusi}

Berdasarkan dari hasil analisis masalah dapat disimpulkan bahwa kurangnya informasi yang didapatkan oleh ibu hamil tentang persiapan persalinan dan kelahiran di masa pandemi COVID-19.

\section{HASIL DAN PEMBAHASAN}

Setelah surveimelalui google form dan kunjungan rumah dilaksanakan di wilayah kerja puskesmas dengan pemberian penyuluhan yang dilaksanakan dengan intervensi melalui group whatsapp menggunakan video yang berisi informasi seputar persiapan persalinan di masa pandemic COVID-19 dan bagi ibu hamil yang tidak masuk dalam group whatsapp dilakukan kunjungan ke rumah masing-masing dengan tetap menerapkan protocol kesehatan COVID-19. Jumlah pernyataan yang diberikan kepada peserta penyuluhan sebanyak 15 pernyataan tertutup (benar salah) yang dibuat melalui google form dan lembar kuesioner bagi peserta penyuluhan yang kunjungan rumah. Setelah pretest diberikan dilanjutkan pemberian kuesioner posttest setelah penyuluhan dan didapatkan hasil bahwa terdapat peningkatan pengetahuan terhadap peserta penyuluhan. Pada kelompok yang memakai google form pengetahuan pretest didapatkan nilai rata-rata $49 \%$ meningkat setelah posttest menjadi $89 \%$. Sedangkan pada kelompok yang 
kunjungan rumah pengetahuan pretest didapatkan hasil 47\% meningkat setelah posttest menjadi $87 \%$.

\section{Penyuluhan Materi}

Persiapan melahirkan di tengah pandemic COVID-19, ada beberapa hal penting yang perlu diperhatikan yaitu:

1. Perlindungan diri

Mendekati waktu melahirkan, jadwal pemeriksaan kehamilan ke dokter kandungan atau bidan juga menjadi lebih sering. Artinya, ibu hamil jadi lebih sering keluar rumah,untuk mengurangi risiko tertular virus Corona, penting sekali bagi ibu hamil untuk melakukan tindakan pencegahan, di antaranya dengan:

- Mencuci tangan sesering mungkin menggunakan air dan sabun atau hand sanitizer yang kadar alkoholnya minimal 60\%

- Tidak keluar rumah dulu, kecuali bila ada keperluan mendesak, dan tidak bepergian ke tempat yang ramai

- Melakukan physical distancing, yaitu menjaga jarak setidaknya 1 meter dari orang lain, saat berada di luar rumah

- Menggunakan masker kain bila hendak keluar rumah

- Menghindari kontak dengan orang sakit

- Tidak menyentuh mata, hidung, dan mulut jika belum mencuci tangan

- Menerapkan etika batuk dan bersih

Selain itu, jaga daya tahan tubuh dengan mengonsumsi makanan bergizi, berolahraga secara rutin, dan tidur yang cukup. Minumlah suplemen kehamilan sesuai anjuran dokter dan jangan lupa periksakan kehamilan ke dokter sesuai jadwal yang ditentukan.

\section{Pilihan tempat melahirkan}

Pilihan tempat melahirkan, baik itu di rumah, klinik, atau rumah sakit, juga perlu ibu hamil pikirkan baik-baik dengan mempertimbangkan risiko dan manfaatnya. Diskusikanlah dulu hal ini dengan dokter. Bila ibu hamil ingin melahirkan di klinik atau di rumah, pastikan ada ambulans atau kendaraan yang dapat menjangkau tempat bersalin. Hal ini untuk berjaga-jaga bila harus segera dirujuk ke rumah sakit.

Jika ibu hamil menderita COVID-19 atau mungkin memiliki gangguan kesehatan tertentu, sebaiknya jangan melahirkan di rumah. Akan lebih aman bila melahirkan di rumah sakit agar kondisi dapat diawasi secara ketat dan bayi dapat dilindungi semaksimal mungkin selama proses persalinan maupun setelahnya. Untuk melahirkan di rumah sakit, tentukanlah dulu rumah sakit mana yang akan menjadi tempat melahirkan sejak jauh-jauh hari. Ibu hamil juga harus kontrol ke dokter kandungan untuk mengetahui waktu perkiraan persalinan.

Selama proses persalinan di rumah sakit, baik dengan operasi caesar maupun normal, ibu boleh ditemani. Namun, pendamping sebisa mungkin dibatasi hanya satu orang.Meski begitu, jika pendamping memiliki gejala COVID-19 atau sedang tidak sehat, ia tidak diizinkan masuk ke ruang bersalin. Hal ini dilakukan agar ibu hamil, bayi, dan dokter atau bidan yang membantu persalinan tidak tertular virus Corona.

\section{Penanganan khusus bagi ibu hamil yang mengalami gejala COVID-19}

Bila ibu hamil merasakan gejala-gejala COVID-19, seperti demam, batuk, dan sesak napas, segera lakukan isolasi mandiri. Ibu hamil dengan COVID-19 tetap bisa bebas memilih metode melahirkan yang akan dijalaninya, namun harus dirujuk ke rumah sakit rujukan COVID-19 terdekat untuk menjalani isolasi dan diberikan penanganan khusus, baik itu menjelang persalinan, saat proses persalinan, maupun setelah bayinya lahir.

Selama masa isolasi, ibu hamil dengan COVID-19 akan tetap mendapatkan perawatan dan pengawasan kehamilan, fasilitas melahirkan yang memadai, serta dukungan moril. Selain itu, bayi yang dilahirkan juga akan tetap mendapatkan ASI serta perawatan dan pengawasan. Persiapan melahirkan di tengah pandemi COVID-19 memang bisa membuat ibu hamil jadi bingung dan stres. 
Namun, tidak perlu khawatir, karena ibu hamil dan buah hati akan tetap mendapatkan pelayanan terbaik, meskipun ada satu atau dua hal yang berbeda dari prosedur persalinan yang biasanya dilakukan.

Agar proses persalinan nanti berjalan lancar, rencanakan baik-baik persiapan melahirkan sejak memasuki pertengahan trimester ketiga. Ibu hamil juga bisa mulai menyiapkan barangbarang yang perlu dibawa ke rumah sakit.

\section{Evaluasi Peningkatan Pengetahuan}

Setelah kegiatan penyuluhan ini dilaksanakan didapatkan peningkatan pengetahuan ibu hamil serta kurangnya kecemasan dalam menghadapi persalinan karena mereka telah mengetahui persiapan yang dilakukan di masa pandemi ini. Hasil Peningkatan ini dapat dilihat melalui grafik dibawah ini.

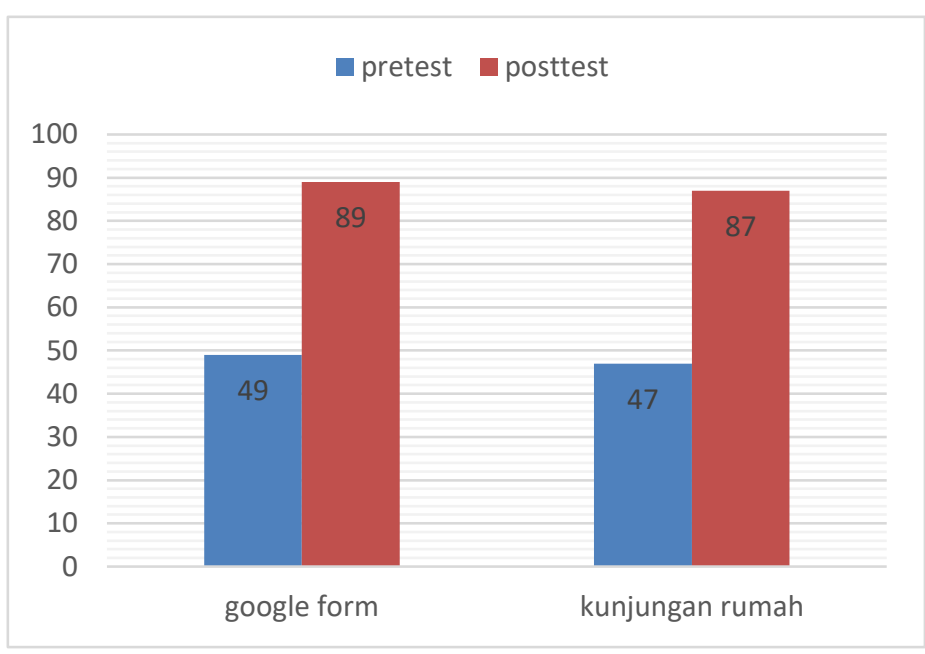

Gambar 2. Peningkatan Pengetahuan Pada Peserta Penyuluhan

\section{KESIMPULAN}

Hasil pengabdian masyarakat ini menunjukan adanya peningkatan pengetahuan dalam persiapan persalinan selama masa pandemi. Selain itu kegiatan ini mendapat respon baik dan didukung oleh masyarakat serta pemerintah.

\section{UCAPAN TERIMA KASIH}

Terima kasih tim ucapkan kepada seluruh pihak yang telah membantu kegiatan ini terlaksana terutama direktur sekolah pascasarja Universitas Hasanuddin, Pihak pemerintah setempat dan para tim.

\section{DAFTAR PUSTAKA}

[1] Yuliana, Corona virus diseas (COVID-19); sebuah tinjauan literatur, Wellness Heal Mag, 2(1), hal.87-92, 2020.

[2] WHO, COVID-19 situation report, Corona virus Dis-2019, 2020

[3] Dashraath, P., Wong, J. L. J., Lim, M. X. K., Lim, L. M., Li, S., Biswas, A., ... Su, L. L. (2020). Coronavirus disease 2019 (COVID-19) pandemic and pregnancy. American Journal of Obstetrics and Gynecology, 222(6), 521-531. https://doi.org/10.1016/j.ajog.2020.03.021

[4] B.S. Mózo, Pedoman permberdayaan masyarakat dalam pencegahan COVID-19 di RT/RW/Desa. J Chem Inf Model, 53(9):1689-99

[5] Kementerian Kesehatan RI. Pedoman bagi ibuhamil, nifas, bersalin, dan bayi baru lahir di erapandemi COVID-19. Jakarta: Kementerian Kesehatan RI, 2020 